\title{
Thoughts on Moral Education of College Students in Network Era
}

\author{
Juan Xue \\ School of Educational Science, Henan University, Kaifeng, 475001, China
}

\begin{abstract}
Keywords: network; moral education of college students; challenge; strategy
\end{abstract}
\begin{abstract}
Network era is an era of information explosion. Living styles, learning modes and recreation ways of college students change profoundly. Meanwhile, various bad ideological trends and potential risks also deeply influence college students' ideas. Analysis of challenges of moral education work in network era and proposal of strategies for moral education work in network era has critical significance to help students form correct outlook on life, view on the world and values and promote their healthy growth.

College period is an important period for college students to form outlook on life, view on the world and values. Some bad information and ideological trends from network impose bad influences on college students' ideological morality. College moral education work undertakes the important task to guide students to establish correct ideological ideas and resist bad social ideological trend. In network era, how to reduce negative effects of network on moral education of college students and improve moral education work level with the help of network is a significant topic of college moral education workers should pay attention to.
\end{abstract}

\section{Challenges for moral education of college students in network era}

Network is a double-edged sword. On the one hand, it can promote implementation of moral education of college students; on the other hand, it can also hinder in-depth implementation of this work. Due to the lack of knowledge and experience, many college students cannot well distinguish network culture and thoughts and thus may be easily misled. This goes against college students to form healthy mentality and favorable personality.

\section{(1) To influence formation of correct "three views" of college students}

Network information is characterized by openness, universality and sharing [1]. So, it contributes to college students to learn new thoughts and absorb new ideas. Meanwhile, lawbreakers will utilize these characteristics to spread some culture and ideology against socialism spiritual civilization construction to impose bad influences on thoughts of college students. From the perspective of the age, outlook on life, view on the world and values of college students are in the formation stage. Due to the effects of mentality, physiology and thoughts, college students are easily influenced by bad thoughts and radical speeches to discard fine traditions of diligence, thrift, working hard and struggling and give up the firm belief of serving the country and making progress.

\section{(II) Improper applications makes students caught in network crime}

As network technology popularizes, out of flaunt mentality or wrong ideological guidance, some college students mastering the technology impurely use advanced network technology and are caught in the wrong way of network crime. To be more specific, network crime of college students are reflected in the following. Firstly, doers utilize programming, decoding and other computer technologies or relevant tools to implement network crimes [2]; secondly, doers utilize defects of various software instructions, network systems and clauses to carry out mutual crimes via network; thirdly, lawbreakers utilize universality, quickness and openness features of network to spread bad thoughts and speeches and induce college students to commit a crime. Besides, some even regard network as tool to directly commit a crime. They utilize features of network, spread various bad thoughts against socialism spiritual civilization construction and infringe physical and psychological health of college students.

Meanwhile, rampant network crimes result in many harmful social phenomena. Currently, some hackers utilize various techniques and means to infringe the information of others or collectivities and wantonly spread all kinds of virus. Some even endanger national security and social stability. Some college students fail to cognize the damages. Some even regard hackers as their idols. This 
seriously hinders sound development of network and formation of good social mood.

(III) College students excessively depend on network and ignore theoretical study and practice

In current society, network can provide a large quantity of useful information and rapidly spread information, but this does not means knowledge explosion. If college students excessively depend on network and give up the opportunities of theoretical study and practice, this will certainly cause that they lack knowledge and experience. Reading materials and learning knowledge via internet will reduce one's reading, expressing and thinking ability. Network prevalence makes college students spend more time on network and reduce face-to-face communication with the society and families. This to some extent will lower communication competence of college students and go against their sound development.

Network world is rich and colorful, but it is not real after all. Long-term indulgence in network will make college students generate dependence on thoughts, thus leading to emotional indifference, solitariness and other mental health problems [3]. Network is a double-edged sword for college students. On the one hand, it can provide cutting-edge science, technology and information and help college students continuously perfect and develop them. On the other hand, due to imperfect network system and psychological and physiological characteristics of college students, network will also give rise to some harmful thoughts to development of college students and social progress. To make internet we contribute to society and college students, it is required to reinforce network ideological and moral education for college students.

(IV) Indulgence in network may easily lead to psychological problems

Network as an important constituent part of the life of modern college students has gradually influenced mental and physical healthy development of college students. When college students enter network, it seems that they enter another world where they can exist with another identity, do those which cannot be realized in real life and live an ideal life. Excessive indulgence in network may easily make college students have psychological problems. For example, firstly, college students form personality disorders such as offensive type, retreat type, dual type and multiple type. Secondly, emotional entanglement may occur, such as puppy love and polygonal love. Thirdly, they may form solitary and indifferent character which affects interpersonal relationship. In particular, some introvert students more easily seek so-called "bosom friends" and "friends" on network. They indulge it for a long time, increasingly depend on network and gradually keep away from sociality and crowds. Thus, they become more solitary.

\section{Strategies to carry out moral education for college students in network era}

\section{(I) To improve moral education contents and innovate for moral education methods}

Enhancement of college students' identification ability for network information and their defense capability is the key to ideological and political education [4]. So, various colleges should construct 3D moral education bases, organically combine real education and network education, optimize moral education structure and contents, innovate for moral education methods and enhance college students' identification ability for network information. The specific measures are as follows:

\section{To enhance reform and innovation of moral education contents}

Colleges should enhance reform and innovation of moral education contents, optimize and improve the contents, regard college ideological and political class as the main base, conform to changes and development of Chinese and foreign situations, make ideological and political education course adapt continuous update and change of network society and give traditional "ideological and political education course" some new vigor and strength. Specific requirements are as follows:

Firstly, utilize modern network and multimedia technology to research, develop and introduce advanced education software and electronic teaching materials; enrich contents and modes of ideological and political education course and make it become interesting from dullness; mobilize learning initiative of college students so as to better reach the purpose of college ideological and political education course.

Secondly, carry out digital design of college ideological and political education course; research 
and develop recreation software which permeates in the course and fuse moral education contents in the games in flexible form; improve students' learning interest and enhance communications among students and between students and teachers; boost the infectivity and emissive power of college ideological and political education course on students.

\section{To innovate for moral education methods}

Specifically speaking, it is required to organically combine moral education work with modern educational technology, give play to the important functions of network in boosting moral education work efficiency. To reach this, the following two aspects should be made:

Firstly, utilize multimedia technology and network technology to prepare sufficient moral education materials; adopt advanced teaching mode to activate classroom atmosphere, enhance students' learning interest and improve classroom efficiency so $s$ to reach the optimal teaching effects.

Secondly, organically combine network technology and moral education contents, focus on theoretical teaching and enhance students' political direction and guide them to establish correct ideas and beliefs. Traditional media go through strict filtering and screening when spreading information, so they have high public recognition degree. Colleges can combine campus broadcast, campus newspapers and periodicals with network, utilize public opinions to conduct comprehensive guidance and education of students.

\section{(III) To eliminate network psychological disorder and promote heart deconstruction and} reconstruction

Network is a virtual and ideal world and owns the features of mystique, stealthiness and virtuality. In complex virtual world, how to achieve ideological guidance of college students is a difficulty problem for college moral education in network era. To really solve this problem, it is required to eliminate network psychological disorder of college students and promote their heart deconstruction and reconstruction.

The author considers moral education should be organically combined with psychological counseling. From the perspective of psychology, formation of healthy thought and noble personality needs a repeated psychological process from practice to theory and then from theory to practice. So, only when colleges start with ideological education and psychological counseling can they better help college students to form favorable quality and personality in network era. To be more specific, the following aspects should be paid attention to:

Firstly, teachers should timely master ideological changes of college students, know the reasons of negative emotion, provide certain abreacting approaches and timely carry out psychological counseling to avoid psychological disorders. On this basis, teachers should also apply their knowledge and morality to influence students and educate them and help them form positive personality trait.

Secondly, teachers should stick to people first, give full play to the dominant role of students, respect their opinions, cultivate independent personality, adopt personalized teaching modes and establish a fair, just, democratic and harmonious communication platform with students.

Thirdly, teachers should guide college students to form good psychological quality and character and cultivate their ability to cope with difficulties and resist setbacks.

Fourthly, college students own abundant ideology, independent personality and dignity, so moral education personnel should listen attentively to college students and know their ideas.

Fifthly, teachers should respect college students' ideas and opinions and avoid forcibly infuse their own ideas to students. If students have different opinions, teachers should listen attentively to them, timely affirm correct views and provide timely guidance for wrong views, communicate with students spiritually and cultivate students' healthy personality.

(IV) To open up new moral education modes with the help of popular propagation modes

In terms of using latest science and technology, educators often fall behind educates. Colleges and teachers should timely optimize moral education modes with the help of QQ, WeChat and microblog and fully utilize these new techniques to create all-around moral education environment.

On the one hand, campus network commentator team should be built. Some students publish 
radical speeches, lack the ability to distinguish news media information and own negative outlook on life. Aiming at these problems, all kinds of colleges should select excellent personnel from students and teachers to build a commentator team to correctly guide students' ideology and behaviors.

On the other hand, it is required to enhance the attraction of campus mainstream media. Colleges should take full advantage of campus media to attract students, spread correct public opinions and thoughts, guide them to establish correct outlook on life and values. Some colleges establish campus microblog, encourage students to form media groups, construct network media, give full play to students' dominant role, mobilize their enthusiasm, help them for self-education and open up new modes for college moral education work.

\section{(V) To perfect moral education guarantee system and guarantee implementation of moral education}

To perfect moral education guarantee system, colleges and the society should do the following:

Firstly, colleges should reinforce research of policy orientation of college student cultivation mode and overall scientific research planning in network society, master well ideological and political education, support and encourage implementation of the work at policy level.

Secondly, it is required to construct thorough guarantee system, arrange research work rationally and orderly, supplement materials about how to better cultivate college students in network society, establish reward mechanism and encourage teachers to take active part in researches.

Thirdly, it is required to build a teacher team dominated by college teachers in ideology and politics, explore and research effective ways to cultivate and educate college students in network society and formulate a set of college student cultivation system with balanced development in class and after class.

Fourthly, it is required to strengthen network supervision, perfect network management system, avoid communication of junk information. College students as an independent group should abide by network system and articles, improve overall quality, cultivate lofty sentiment and quality, establish good network interpersonal relationship and create good network atmosphere.

\section{Conclusions}

On a world, colleges should fully cognize huge adjustment of college moral education work in network era and specify the importance of network in college moral education work. Meanwhile, colleges should enhance innovation of relevant researches on moral education modes in network era, incorporate network moral education into post duties of moral education teachers, combine new features of college students in network era to rationally improve and adjust moral education modes with education as the objective and promote college students to become useful persons as early as possible.

\section{References}

[1] Cao Hongchen, Defects of moral education of college students and improvement measures [J]. Front, 2012, 21:168-169

[2] Bi Yimin, Approaches for college libraries to realize moral education of college students in network environment [J]. China Adult Education, 2009, 09:58-59

[3] Huang Xiaowei, Analysis of challenges of moral education of college students in new period [J]. China Adult Education, 2008, 04:74.

[4] Zhao Guofeng, Moral education of college students in network era [J]. Academic Forum, 2005, 09:183-186. 